\title{
Problems associated with alcohol consumption by university students
}

\author{
Guillermo Alonso Castaño-Perez ${ }^{1}$ \\ Gustavo Adolfo Calderon-Vallejo ${ }^{2}$
}

Objectives: the aim of this study was to analyze alcohol consumption by university students and psychosocial problems related. Method: descriptive correlational study that included 396 university students. The "Alcohol Use Disorders Identification Test" - (AUDIT) - and an "ad hoc" questionnaire were used as instruments to assess the associated problems. Results: of the total sample, $88.6 \%$ drank, $20.5 \%$ had harmful consumption and $14.9 \%$ were at risk of dependence according to AUDIT. The study showed important results related to harmful alcohol consumption and dependence, with damage to the academic performance, social relationships, psychological status and sexual condition. Conclusions: complications caused by problematic alcohol consumption by university students, which is high in this group due to the high prevalence of their alcohol consumption, highlights the importance of promoting programs to prevent the abuse and dependence of this substance in universities.

Descriptors: Alcohol Drinking; Students; Social Problems.

\footnotetext{
${ }^{1}$ PhD, Associate Professor, Escuela de Postgrados, Fundación Universitaria Luis Amigó, Medellín, Colombia.

2 MSc, Associate Professor, Facultad de Psicología y Ciencias Sociales, Fundación Universitaria Luis Amigó, Medellín, Colombia.
}

Corresponding Author:

Guillermo Alonso Castaño-Perez

Fundación Universitaria Luis Amigó. Facultad de Psicología y Ciencias Sociales

Transversal, 51A, \#67B, 90

Medellín, Colombia

E-mail: gcastano@funlam.edu.co
Copyright (c) 2014 Revista Latino-Americana de Enfermagem This is an Open Access article distributed under the terms of the Creative Commons Attribution Non-Commercial License (CC BY-NC).

This license lets others distribute, remix, tweak, and build upon your work non-commercially, and although their new works must also acknowledge you and be non-commercial, they don't have to license their derivative works on the same terms. 


\section{Introduction}

The study of alcohol consumption by university students has generated interest in all cultures and all continents. Studies to explain the intake of this substance in this population began in the mid-seventies in industrialized countries ${ }^{(1-2)}$. From the eighties, there were reports on high alcohol consumption and problems associated with alcohol abuse in this population group ${ }^{(3)}$. Some authors report a greater likelihood of use of psychoactive substances through adolescence and early adulthood, with a positive association between educational level and consumption(4).

The problems resulting from alcohol consumption in young people are different from those in adults. In young people, the negative effects deriving from alcohol consumption often involve changes in the relationship with family, peers and teachers, poor school performance, aggression, crime, public disorder and high-risk behaviors, such as driving after drinking, as well as unprotected sexual activities, involving unintended pregnancy and sexually transmitted diseases(5-6). In general, students who drink large amounts of alcohol have more risk behaviors for themselves and for the others compared to students who do not drink(7).

In the same context, it has been argued that alcohol abuse and alcoholism participate directly and indirectly in the development of physical, mental and social damages ${ }^{(8)}$, besides affecting others and producing domestic violence, marital conflicts, economic problems, fights with injuries and traffic accidents ${ }^{(9-10)}$. All these problems not only affect the physical, emotional and social development of young people, but also their permanence at university and the quality of their training for working life.

This research is focused on the analysis of the problems associated with the consumption of this substance according to the "Alcohol Use Disorders Identification Test" - AUDIT - and its correlation with problems in academic performance, relationships, family, psychological and sexual areas, in a sample of university students, thus contributing to the knowledge, because studies rarely address such associations, specifically in this population.

\section{Methods}

This was a cross-sectional, descriptive correlational study, which investigated the problems associated with alcohol consumption in a sample of university students, according to the risks of the AUDIT scale.

\section{Sample}

Stratified random sampling was used to calculate the sample size, considering the number of students enrolled in the first semester of 2010 at a university, in which the following parameters were considered: population size of 6,288 students; expected proportion of alcohol consumption of $88.0 \%$, a confidence level of $95 \%$ and a design effect of 1.5 . The sample size included in the study was 396 students of both sexes, aged between 15 and 49 years.

\section{Instruments}

Questionnaire "ad hoc" to determine the sociodemographic characteristics and the difficulties associated with alcohol consumption: information collection on age; gender; marital status; socioeconomic status, assessed according to the classification proposed by the National Bureau of Statistics of Colombia; semester the student is enrolled in; alcohol consumption; age of first use; problems related to their academic performance; risks associated with their sexuality; physical aggressions; traffic accidents; problems with the authorities; changes in their physical or mental health, diagnosed by the university physician together with the clinical history and the clinical examination, among other characteristics, medical psychometric tests, the Zung test for depression and Hamilton test for anxiety; and family and social problems reported by the students themselves. This instrument was validated by three experts in drugs research (two psychiatrists and a sociologist) and through a pilot test applied to 30 individuals of the same university, college students who were not included in the final sample.

The "Alcohol Use Disorders Identification Test" AUDIT- was developed by the World Health Organization (WHO), and approved in Colombia for the university population by Londoño(11), resulting in Cronbach's alpha values of 0.86 and 0.90 in the test and re-test, respectively. The AUDIT includes questions about the consequences of alcohol consumption, along with questions about the amount and frequency of intake. It consists of 10 items, with 5 possible answers, scored from 0 to 4, except items 9 and 10, which score only $0,2,4$. The result is obtained by the sum of the 
domain scores: risk-free consumption, dependence and hazardous consumption.

\section{Procedure for data collection}

Approval was obtained from the directors of the university, who were previously informed on the project objectives. After authorization, the survey was applied in the same selected sample and each of the study participants signed an informed consent.

\section{Data analysis}

The description of the results was based on descriptive statistical instruments and techniques, using SPSS 18.0, according to the variable type. In this context, frequency distributions for qualitative variables and summary central trend measures were performed for the quantitative variables, taking into consideration whether they followed a normal distribution by means of the Kolmogorov-Smirnov test with Lilliefors correction.

After the descriptive process, the association between alcohol consumption and other variables included in the form were estimated by chi-square and Student's t-test in terms of their applicability and considering for statistically significant associations $p \leq$ 0.05 .

\section{Results}

Women represented $60.1 \%$ of the sample, the mean age was 23.2 years $(S D= \pm 5.7)$ and $75 \%$ of the sample was between 18 and 25 years, mostly single (81.6\%) and belonging to the socio-economic groups 3 and $4(74.7 \%)$ (Table 1$)$.

With regard to alcohol consumption, 88.6\% (351) of the respondents reported alcohol consumption across the lifetime. The mean age of onset of alcohol consumption was 14.4 years $(S D= \pm 3.2)$, and $11.3 \%$ did so before age 10 and $58.7 \%$ had experienced it between age 11 and 15 years old.

According to the AUDIT score, $64.6 \%$ had no problems with alcohol, while $20.5 \%$ showed hazardous drinking and $14.9 \%$ were at risk of dependence.

Regarding the presence of problems related to the academic performance and the Alcohol Use Disorders Identification Test - AUDIT-, statistically significant associations were found, which shows that, the greater the problem of hazardous consumption or dependence, the greater the significance $(p=0.000)$.
Table 1 - Socio-demographic data. Alcohol consumption and related problems in university students. Medellin, Colombia, $2010(\mathrm{~N}=396)$

\begin{tabular}{lc}
\hline \multicolumn{1}{c}{ Variable } & Results $\mathbf{N}(\%)$ \\
\hline Age $^{*}$ & $(13) 3.3 \%$ \\
Under 18 years old & $(297) 75 \%$ \\
$18-25$ years old & $(86) 21.7 \%$ \\
Over 25 years & \\
Gender & $(238) 60.1 \%$ \\
Female & $(158) 39.9 \%$ \\
Male & \\
Marital status & $(323) 81.6 \%$ \\
Single & $(38) 9.6 \%$ \\
Married & $(27) 6.8 \%$ \\
Engaged & $(8) 2 \%$ \\
Separated & \\
Socio-economic level & \\
Section 1 e 2 & $(71) 18 \%$ \\
Section 3 & $(198) 50 \%$ \\
Section 4 & $(98) 24.7 \%$ \\
Section 5 e 6 & $(27) 6.8 \%$ \\
\hline
\end{tabular}

* Mean age: 23.2 years $(S D=5.7)$

+ In Colombia, the socio-economic stratification occurs from 1 to 6 , with 1 being the lowest and 6 the highest. This classification is made by the National Administrative Department of Statistics - NADS - according to the type of residence and all the amenities it contains.

Among the problems presented in the cases of abuse or addiction to psychoactive substances, the absences and delays in the classes are highlighted $(37.3 \%$ if there is hazardous consumption and $67.4 \%$ if there is dependence) and low academic performance (16.4\% in the consumption abuse and $52.2 \%$ if there is dependence (Table 2).

Table 2 - Academic problems and their correlation with the AUDIT. Alcohol consumption and related problems in university students. Medellin, Colombia, $2010(\mathrm{~N}=351)$

\begin{tabular}{|c|c|c|c|c|c|c|}
\hline \multirow{2}{*}{$\begin{array}{c}\text { Academic problems } \\
\text { and AUDIT }\end{array}$} & \multicolumn{2}{|c|}{ Yes } & \multicolumn{2}{|c|}{ No } & \multirow{2}{*}{ Total } & \multirow{2}{*}{$P$ value } \\
\hline & $\mathbf{n}$ & $\%$ & $\mathbf{n}$ & $\%$ & & \\
\hline $\begin{array}{l}\text { Absences or delays in } \\
\text { the classes }\end{array}$ & & & & & & $\leq 0.001$ \\
\hline Risk-free consumption & 24 & 12.3 & 171 & 87.7 & 195 & \\
\hline $\begin{array}{l}\text { Hazardous } \\
\text { consumption }\end{array}$ & 41 & 37.3 & 69 & 62.7 & 110 & \\
\hline Dependence & 31 & 67.4 & 15 & 32.6 & 46 & \\
\hline $\begin{array}{l}\text { Low academic } \\
\text { performance }\end{array}$ & & & & & & $\leq 0.001$ \\
\hline Risk-free consumption & 5 & 2.6 & 190 & 97.4 & 195 & \\
\hline $\begin{array}{l}\text { Hazardous } \\
\text { consumption }\end{array}$ & 18 & 16.4 & 92 & 83.6 & 110 & \\
\hline Dependence & 24 & 52.2 & 22 & 47.8 & 46 & \\
\hline
\end{tabular}

Statistical significance was also found by relating problems in personal, sexual and physical health aspects with drinking practices, according to the AUDIT classification. 
Sexually Transmitted Diseases were more frequent in people with risk drinking (3.6\%) and dependence (8.7\%) according to the AUDIT, with a statistical association and $\mathrm{p} \leq 0.005$. A statistical association between AUDIT and unintended pregnancy was also observed in this sample $(p=0.02)$. Among those presenting risk drinking, $7.3 \%$ had unintended parenthood, increasing the percentage to $13.0 \%$ in those who scored at risk of dependence. General health problems (headache, joint pain, gastrointestinal disorders) are also more frequent among those who score at risk for dependence (41.3\%) or hazardous consumption (18.2\%), with statistically significant results $(p=0.000)$.

Physical aggressions are also more common among those with dependence $(21.7 \%)$, as well as traffic accidents $(13.0 \%)$ and problems with the authorities (23.9\%) (Table 3).

When analyzing the correlation between the AUDIT classification and alcohol consumption effects on social and familial relationships, significant associations were observed between fights and arguments with friends ( $p \leq 0.001)$, fights and arguments with strangers ( $p \leq$ $0.001)$, loss of friends ( $p=0.009)$, loss of partners ( $p \leq$ $0.001)$ and conflicts with parents $(p \leq 0.001)$. Fights and arguments with friends are the most frequent problems (25.5\% in case of abusive consumption and $52.2 \%$ if there is dependence); followed by conflicts with parents (25.5\% if there is consumption of risk and $50 \%$ if there is dependence), fights and arguments with strangers (14.5\% and $41.3 \%$ if abuse occurs, if dependence occurs) and a small percentage of loss of partners and friends (Table 4).

Last but not least are the psychological problems among consumers who have difficulties with alcohol consumption according to the AUDIT. Statistical significance ( $p \leq 0.001$ ) was observed for each of the variables considered: depression (some degree, according to the test Zung), anxiety (some degree according to Hamilton's test), emotional oscillations (dysthymia), irritability and low tolerance. The major problems occurring in this area are the emotional oscillations, $50.0 \%$ if the consumption is rated according to the AUDIT as hazardous and $56.5 \%$, if what occurs is dependence. Then comes anxiety $(37.3 \%$ in cases of abusive consumption and $50.0 \%$ for dependence), depression (34.5\% if there is hazardous consumption and $47.8 \%$ if dependence occurs) and irritability and low tolerance $(21.8 \%$ in case of hazardous consumption and $37 \%$ for dependence) (Table 5).

Table 3 - Personal problems and their correlation with the AUDIT. Alcohol consumption and related problems in university students. Medellin, Colombia, $2010(\mathrm{~N}=351)$

\begin{tabular}{|c|c|c|c|c|c|c|}
\hline \multirow{2}{*}{ Personal problems and AUDIT } & \multicolumn{2}{|c|}{ Yes } & \multicolumn{2}{|c|}{ No } & \multirow{2}{*}{ Total } & \multirow{2}{*}{$P$ value } \\
\hline & $\mathbf{n}$ & $\%$ & $\mathbf{n}$ & $\%$ & & \\
\hline Infection with STDs & & & & & & 0.005 \\
\hline Risk-free consumption & 1 & 0.5 & 194 & 99.5 & 195 & \\
\hline Hazardous consumption & 4 & 3.6 & 106 & 96.4 & 110 & \\
\hline Dependence & 4 & 8.7 & 42 & 91.3 & 46 & \\
\hline Unwanted parenting & & & & & & 0.022 \\
\hline Risk-free consumption & 6 & 3.1 & 189 & 96.9 & 195 & \\
\hline Hazardous consumption & 8 & 7.3 & 102 & 92.7 & 110 & \\
\hline Dependence & 6 & 13.0 & 40 & 87.0 & 46 & \\
\hline Physical aggressions & & & & & & 0.000 \\
\hline Risk-free consumption & 5 & 2.6 & 190 & 97.4 & 195 & \\
\hline Hazardous consumption & 6 & 5.5 & 104 & 94.5 & 110 & \\
\hline Dependence & 10 & 21.7 & 36 & 78.3 & 46 & \\
\hline Traffic accident as a driver or pedestrian & & & & & & 0.022 \\
\hline Risk-free consumption & 6 & 3.1 & 189 & 96.9 & 195 & \\
\hline Hazardous consumption & 8 & 7.3 & 102 & 92.7 & 110 & \\
\hline Dependence & 6 & 13.0 & 40 & 87.0 & 46 & \\
\hline Problems with the authorities for driving under the influence of alcohol & & & & & & 0.000 \\
\hline Risk-free consumption & 3 & 1.5 & 192 & 98.5 & 195 & \\
\hline Hazardous consumption & 6 & 5.5 & 104 & 94.5 & 110 & \\
\hline Dependence & 11 & 23.9 & 35 & 76.1 & 46 & \\
\hline Health problems & & & & & & 0.000 \\
\hline Risk-free consumption & 8 & 4.1 & 187 & 95.9 & 195 & \\
\hline Hazardous consumption & 20 & 18.2 & 90 & 81.8 & 110 & \\
\hline Dependence & 19 & 41.3 & 27 & 58.7 & 46 & \\
\hline
\end{tabular}


Table 4 - Social and family problems and their correlation with the AUDIT. Alcohol consumption and related problems in university students. Medellin, Colombia, $2010(\mathrm{~N}=351)$

\begin{tabular}{|c|c|c|c|c|c|c|}
\hline \multirow{2}{*}{ Social and familial problems and AUDIT } & \multicolumn{2}{|c|}{ Yes } & \multicolumn{2}{|c|}{ No } & \multirow{2}{*}{ Total } & \multirow{2}{*}{ Value $p$} \\
\hline & $\mathbf{n}$ & $\%$ & $\mathbf{n}$ & $\%$ & & \\
\hline Fights and arguments with friends & & & & & & $\leq 0.001$ \\
\hline Risk-free consumption & 26 & 13.3 & 169 & 86.7 & 195 & \\
\hline Hazardous consumption & 28 & 25.5 & 82 & 74.5 & 110 & \\
\hline Dependence & 24 & 52.2 & 22 & 47.8 & 46 & \\
\hline Fights and arguments with strangers & & & & & & $\leq 0.001$ \\
\hline Risk-free consumption & 12 & 6.2 & 183 & 93.8 & 195 & \\
\hline Hazardous consumption & 16 & 14.5 & 94 & 85.5 & 110 & \\
\hline Dependence & 19 & 41.3 & 27 & 58.7 & 46 & \\
\hline Loss of friends & & & & & & 0.030 \\
\hline Risk-free consumption & 11 & 5.6 & 184 & 94.4 & 195 & \\
\hline Hazardous consumption & 11 & 10.0 & 99 & 90.0 & 110 & \\
\hline Dependence & 8 & 17.4 & 38 & 82.6 & 46 & \\
\hline Loss of partners & & & & & & $\leq 0.001$ \\
\hline Risk-free consumption & 12 & 6.2 & 183 & 93.8 & 195 & \\
\hline Hazardous consumption & 14 & 12.7 & 96 & 87.3 & 110 & \\
\hline Dependence & 18 & 39.1 & 28 & 60.9 & 46 & \\
\hline Conflict with parents & & & & & & $\leq 0.001$ \\
\hline Risk-free consumption & 19 & 9.7 & 176 & 9.3 & 195 & \\
\hline Hazardous consumption & 28 & 25.5 & 82 & 74.5 & 110 & \\
\hline Dependence & 23 & 50.0 & 23 & 50.0 & 46 & \\
\hline
\end{tabular}

Table 5 - Psychological problems and their correlation with the AUDIT. Alcohol consumption and related problems in university students. Medellin, Colombia, 2010 (N=351)

\begin{tabular}{|c|c|c|c|c|c|c|}
\hline \multirow{2}{*}{ Psychological problems and AUDIT } & \multicolumn{2}{|c|}{ Yes } & \multicolumn{2}{|c|}{ No } & \multirow{2}{*}{ Total } & \multirow{2}{*}{$P$ value } \\
\hline & $\mathbf{n}$ & $\%$ & $\mathbf{n}$ & $\%$ & & \\
\hline Depression & & & & & & $\leq 0.001$ \\
\hline Risk-free consumption & 19 & 9.7 & 176 & 90.3 & 195 & \\
\hline Hazardous consumption & 38 & 34.5 & 72 & 65.5 & 110 & \\
\hline Dependence & 22 & 47.8 & 24 & 52.2 & 46 & \\
\hline Anxiety & & & & & & $\leq 0.001$ \\
\hline Risk-free consumption & 17 & 8.7 & 178 & 91.3 & 195 & \\
\hline Hazardous consumption & 41 & 37.3 & 69 & 62.7 & 110 & \\
\hline Dependence & 23 & 50.0 & 23 & 50.0 & 46 & \\
\hline Emocional Oscillations & & & & & & $\leq 0.001$ \\
\hline Risk-free consumption & 38 & 19.5 & 157 & 80.5 & 195 & \\
\hline Hazardous consumption & 55 & 50.0 & 55 & 50.0 & 110 & \\
\hline Dependence & 26 & 56.5 & 20 & 43.5 & 46 & \\
\hline Irritability. low tolerance & & & & & & $\leq 0.001$ \\
\hline Risk-free consumption & 17 & 8.7 & 178 & 91.3 & 195 & \\
\hline Hazardous consumption & 24 & 21.8 & 86 & 78.2 & 110 & \\
\hline Dependence & 17 & 37.0 & 29 & 63.0 & 46 & \\
\hline
\end{tabular}

\section{Discussion}

With regard to alcohol consumption by university students, there are many epidemiological reports conducted in different parts of the world, which differ according to the contexts and cultures. In Canada, in a sample of 6,282 university students, it was observed that alcohol is the most commonly used drug, with a prevalence of $77 \%$ in the past 30 days $^{(12)}$. In the United States and Mexico, the university students generally report high rates of excessive drinking, abuse and dependence ${ }^{(13)}$.

Among university students in the Andean region(14), alcohol consumption is also high. Over $90 \%$ of students 
in Colombia and Peru, and about $75 \%$ in Bolivia and Ecuador, reported alcohol consumption at least once in their lives, values very similar to those found in our study $(88.6 \%)$.

Another finding showing some similarities with our research results is related to alcohol consumption and the classification of the problem according to AUDIT. In the study of the Community of Andean Nations(14) on consumers of alcohol in the past year, about a third part of the students in Bolivia, Colombia, Ecuador, and $21 \%$ in Peru are self classified as consumers of risk or hazardous alcohol consumers. In addition, by evaluating the signs of addiction, it is observed that almost $8 \%$ of university students in Peru, Bolivia 10.5\%, 12\% in Colombia and $16 \%$ in Ecuador, who claim to have consumed alcohol in the last year, can be considered with signs of addiction. In our study, $20.5 \%$ had risk drinking and $14.9 \%$ were at risk of dependence.

The university population is highly vulnerable to alcohol consumption $^{(15-16)}$ due to the ease of buying alcoholic beverages, the availability of consumption situations that occurs by entering the university environment, the independence and autonomy they acquire and on many occasions, the lack of parental control.

In relation to the problems associated with alcohol consumption and their correlation with the AUDIT, no studies were found. Some studies that have been conducted, although very scarce, report the abuse of this substance and the problems caused in university students. It has been reported a higher default and dropout in this population group(17-18). School dissatisfaction, higher amount of repetitions in the courses $^{(19)}$ and larger family and social difficulties(20-22) were also found. These results are similar to those found in our study.

Regarding the general population and students, there are several studies that report on the consequences of the consumption/abuse of this substance in all areas of the individual and a assembly is noted. Although these studies have been conducted in different populations, there are similarities when analyzing the problems caused by alcohol consumption and their impact on the student at work, in family, social relations, accidents, sexual and psychological state, which are probably higher among university students due to higher alcohol consumption in this group. Some results are described below without comparison with our results, because they are not comparable.

The associations between alcohol abuse with increased morbidity, violence, family problems, school dropout and accidents have been reported in different populations ${ }^{(23)}$. The World Health Organization revealed that in 2000, alcohol was responsible for $4.0 \%$ of the global burden of disease related to neuropsychiatric disorders (addiction, psychosis, depression) and unintentional injuries (accidents, burns, drowning and falls) ${ }^{(24)}$ and some authors have called attention to the damage that alcohol abuse causes to health, increasing gastrointestinal and cardiovascular diseases, traffic accidents, violent deaths and the spread of sexually transmitted diseases due to excessive use of this substance and unprotected sexual practices(25-26).

On the other hand, family and social conflicts are other consequences of alcohol abuse among young people. Rejection and isolation occurs as consequence of excessive alcohol consumption (negative prognosis from family, friends and society) and are typical features of this kind of problem(27). Our study also showed association between these problems and hazardous consumption or dependence according to the AUDIT.

\section{Conclusion}

The high prevalence and the associations with the identified problems emphasize the need to create practical interventions within the Universities and to develop public policies for health promotion and disease prevention, such as early pregnancy, mental problems, traffic accidents and many others.

The observations in this study are consistent with those empirically demonstrated by other authors, both in university as students, and reinforce the importance to assess the level of alcohol consumption and damages related to risk drinking and dependence in young people. Therefore, it is necessary to develop effective, efficient and productive prevention strategies and to educate about the drinking limits more than just banning the alcohol consumption. Desiringa sober society in the West is and will always be a utopia, but not when it comes to intervening in university students, whose stages of life include alcohol as part of their social development. 


\section{References}

1. Alvira- Martin F. Pautas de consumo de bebidas alcohólicas entre los jóvenes Españoles. Ministerio de Sanidad y Consumo. Madrid; 1982. 220 p.

2. Brook M, Walfish S, Stenmark D, Canger J. Personality variables in alcohol abuse in college students. J Drug Educ. 1981;11:185-9.

3. O' Conell D, Patterson H.A. Survey of current college alcohol abuse programs, attitudes and training needs. J Alcohol Drug Educ. 1989;43(2):61-9.

4. Velásquez J, Scoppetta O. Consumo de sustancias psicoactivas en estudiantes de carreras técnicas y tecnológicas de Santa Fe de Bogotá. Bogotá; 1998. 80 p. 5. American Academy of Pediatrics. Uso y abuso del alcohol: una preocupación pediátrica. Pediatrics (ed. esp.) 1995;39:188-92.

6. Stueve A, O'Donnell LN. Early alcohol initation and subsequent sexual and alcohol risk behaviours among urban youths. Am J Public Health. 2005;95(4):887-93.

7. Hingson RW, Heeren T, Winter MR. Age at drinking onset and alcohol dependence: Age at onset, duration, and severity. Arch Pediatr Adolesc Med. 2006;160(7):739-46. 8. Gutiahr E, Gmel G, Rehm J. Relation betwin average alcohol consumption and disease: an overview. Eur Addict Res. 2001;7(3):117-27.

9. Tempier R, Boyer R, Lambert J. Psychological distrress among female spouses of male at - risk drinkers. Alcohol. 2006; 40(1):41-9.

10. MacDonald S, Cherpitel CJ, DeSouza A, Stockwell T, Borges G, Giesbrecht N. Variations of alcohol impairment indifferent types, causes and contexts of injuries: Results de emergency room studies from 16 countries. Accid Anal Prev. 2006;38(6):1107-12.

11. Londoño C. Construcción de un modelo cognitivosocial integrado para la prevención del abuso en el consumo de alcohol en universitarios bogotanos. Tesis [Grado]. Programa de Maestría en Psicología de la Universidad Nacional de Colombia; 2004. 254 p.

12. Hingson RW, Heeren T, Winter MR. Age at Drinking Onset and Alcohol Dependence. Arch Pediatr Adolesc Med. 2006;160(7):739-46.

13. Johnston LD, O'Malley PM, Bachman JG, Schulenberg JE. Monitoring the Future national survey results on drug use, 1975-2004: Volume II. Bethesda, MD: National Institute on Drug Abuse; 2007. 326 p.

14. SG-CAN, Unión Europea. Estudio Epidemiológico Andino sobreconsumo de drogas sintéticas en la población universitaria de Bolivia, Colombia, Ecuador y Perú [Internet]. 2009 [acesso 30 out 2012]. Disponivel em: http://www.comunidadandina.org/DS/ Consumo\%20Drogas\%20Informe\%20comparativo.pdf. 15. Flórez L. Diagnóstico e Intervención del Consumo Excesivo de Alcohol en Ambientes Educativos. TIPICA: Boletín Electrónico de Salud Escolar. [Internet] 2007; [acesso 30 out 2012]; 3(2). Disponível em: http://www. henrry.tipica.org/xwuqiwasjlhasdf7985644Tipica2/ presentacion_03_02.html

16. Palma M, Lannini J, Moreno S. Validación de la Prueba Young Adult Alcohol Problems Screening Test, YAAPST, en un grupo de estudiantes universitarios de la Pontificia Universidad Javeriana de Bogotá. Universitas Psychol. 2005;5(1):175-90.

17. Londoño C, García W, Valencia S, Vinaccia S. Expectativas frente al consumo de alcohol en jóvenes universitarios colombianos. Rev Anales Psicol. 2005;21(2):259-67.

18. Crum RM, Ensminger ME, Ro MJ, McCord J. The association of educational achievement and school dropout with risk of alcoholism: A twenty - five year prospective study of inner-city children. J Stud Alcohol. 1998;59(2):318-26.

19. Wichstrom L. Alcohol intoxication and school dropout. Drug Alcohol Rev. 1998;17(4):413-21.

20. López-Frías M, Fernández MF, Planells $E$, Miranda MT, Mataix J, Llopis J. Alcohol consumption and school efficiency in Spanish secondary school students. J Stud Alcohol. 2001;62:741-4.

21. Donovan J. Adolescent Alcohol Initiation: A Review of Psychosocial Risk Factors. J Adolesc Health. 2004;35:529-38.

22. Herrera Paredes JM, Arena Ventura CA. Alcohol consumption and domestic violence against women: a study with university students from Mexico. Rev. LatinoAm. Enfermagem. 2010;18(esp):557-64.

23. Reinaldo AMS, Pillon SC. Alcohol effects on family relations: a case study. Rev. Latino-Am. Enfermagem. 2008;16(esp):529-34.

24. Plan Nacional sobre Drogas. Encuesta domiciliaria sobre alcohol y drogas en España (EDADES), 1995-2007 [Internet]. 2007; [acesso 23 ago 2011]. Disponivel em: http://www.pnsd.msc.es/Categoria2/observa/pdf/ Domiciliaria2007.pdf.

25. Organização Mundial da Saúde. OMS. Alcohol, Gender and Drinking Problems. Perspectives from Low and Middle Income Countries. - GENASIS- OPS- 
Edited by Isidore S. Obot y Robin Room. Geneva: WHO. Department of Mental Health and Substance Abuse; 2005. 241 p.

26. Perez A. Transiciones en el consumo de drogas en Colombia. Adicciones. 2009;21(1):81-8.

27. Calafat Far $A$, Juan Jerez $M$, Duch Moyá MA. Conductas de riesgo de jóvenes turistas españoles de vacaciones en Mallorca e Ibiza: consumo de alcohol, drogas y otros riesgos para la salud. Rev Española Drogodependencias. 2011;36(2):137-48. 